Journal

of Geography

Politics and Society

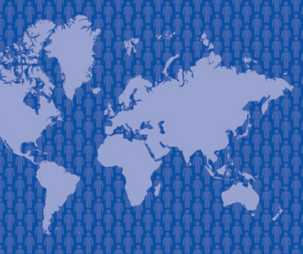

$8(1) / 2018$

\section{Journal of Geography, Politics and Society}

$2018,8(1), 24-40$

DOI 10.4467/24512249JG.18.002.8154

\title{
SOCIAL PROTECTION OF ATO PARTICIPANTS AND THEIR FAMILIES IN UKRAINE: AN ANALYTICAL REVIEW AND PROMISING MEASURES
}

\author{
Tetiana Kotenko (1), Yuliia Horemykina (2) \\ (1) Department of Social Infrastructure, Ptoukha Institute for Demography and Social Studies of the National Academy of Sciences of Ukraine, Taras Shevchenko \\ Boulevard 60, 01032 Kyiv, Ukraine, \\ e-mail: tatyanako@ukr.net (corresponding author) \\ (2) Department for Human Development Studies, Ptoukha Institute for Demography and Social Studies of the National Academy of Sciences of Ukraine, Taras \\ Shevchenko Boulevard 60, 01032 Kyiv, Ukraine \\ e-mail: refer5718@gmail.com
}

\section{Citation}

Kotenko T., Horemykina Yu., 2018, Social protection of ATO participants and their families in Ukraine: an analytical review and promising measures, Journal of Geography, Politics and Society, 8(1), 24-40.

\begin{abstract}
The current situation in Ukraine concerning the guarantee of social protection and providing social services for ATO participants by state and non-governmental organizations is analyzed. Legislative strengthening of social protection of ATO participants is revealed. The current state of the providing of social services for ATO participants and their family members, the effectiveness of the use of resources (financing) for 2014-2016 on the basis of a comparative analysis of the costs on social protection in the expenditures of the Consolidated Budget of Ukraine and presented as a share of GDP, in Ukraine and the European Union countries for 2011-2014, are evaluated. The problems in the field of social protection for ATO participants and and promising measures in this field such as the evaluation of the effectiveness of national and regional social programs for ATO participants and the evaluation of the public expenditures for the social protection of ATO participants and the evaluation of the quality of social services for ATO participants are grounded.
\end{abstract}

\section{Key words}

ATO participants; social protection; social services; social programs; government expenditures.

Received: 13 September 2017

Accepted: 24 November 2017

Published: 30 March 2018

\section{Introduction}

During the recent years as a result of the events in eastern Ukraine two new categories of social service recipients, which are the internally displaced persons and the participants of the antiterrorist operation (ATO) has appeared. These categories require special attention of the state, because the social vulnerability of these persons is a phenomenon that arose suddenly and dramatically change the habitual life of citizens, most of whom did not need a state support until 2014 year or needed it much lesser. Therefore, in order to avoid the increasing of the social vulnerability of these persons, it is necessary to regularly analyze the implemented by the state measures of social policy aimed at supporting internally displaced persons and ATO participants, including the state of the provision of social services 
for them. It should be noted that social services for the internally displaced persons and ATO participants, are also provided by non-governmental organizations that are the social partners of the state. The services of such organizations also require analysis, which will help to find out their potential and to find the most effective ways of cooperation with the state. This research focuses on the second category mentioned above that is the participants of the antiterrorist operation (ATO participants).

Social protection of ATO participants is an integral component of a social policy (Кравченко, 2015; Горбулін et al. (eds.), 2015), a social, economic and political stabilizer of society development (Toпішко, 2014), a factor of minimizing of social risks (Надрага, 2014). Ukrainian researchers studied the main theoretical, methodological and practical problems of social protection of ATO participants (Лаврухін, 2014; Маліновська, Рудзінська, 2013; Марценюк, 2015). In addition, Ukrainian researchers have developed the theoretical approaches to the evaluation of the effectiveness of state social programs, government expenditures (Макарова, 2015; Радіонов, 2013; Лібанова et al. (eds.), 2010) which makes possible to propose the algorithms for the evaluation of the effectiveness of national and regional social programs for ATO participants, social expenditures protection of ATO participants.

The scientific and theoretical analysis of the legislation on social protection of the population and of the normative and legal provision of social protection for ATO participants and their families indicates the need to systematize the legal acts regulating the issues of social protection of ATO participants and their families (Длугопольська, 2016; Ветлинський, 2016; Чижов, 2016). The state institutions have not worked out the integrated approach to improving the financing of the social protection system for ATO participants and their families. Despite the presence of a large number of scientific works on this topic, currently there is no theoretical model of the financial provision of social protection for ATO participants and their families (Ковалевич, 2017; Кучер, 2016; Насібова, 2015; Огінська, 2014; Товстиженко et al., 2014).

\section{Research results analysis}

The main objective of the study is to present an analysis of the current situation in Ukraine concerning the guarantee of social protection and provision of social services to the ATO participants, by the state and non-governmental organizations.
The one of the most important steps in the field of the state social support for ATO participants, became the creation of the State Service of Ukraine for War Veterans and ATO participants in 2014 year (Про утворення..., 2014), which entrusted with the establishing the status of a participant in hostilities to ATO participants, providing them with the social guarantees provided by the legislation, ensuring adaptation and psychological rehabilitation, sanatorium and resort treatment, technical and other means of rehabilitation, social and professional adaptation, providing housing for War Veterans (Каленюк, Котенко, 2016).

In 2015-2016 years a number of measures were taken in Ukraine to increase the level of social and legal safeguards for ATO participants, which include: the legislative strengthening of social protection for ATO participants, the provision of their housing, the provision of social services for them (the provision of sanatorium and resort treatment for the victims of antiterrorist operation, an employment for ATO participants, psychological rehabilitation and social and professional adaptation for ATO participants, provision of other social services for the ATO participants' families) (Алієв, 2017; Пільги..., 2017; Про схвалення Концепції ..., 2017). Let's take a closer look at the steps below.

\subsection{ATO participants and their legal status}

Today the persons who are recognized as the ATO participants, are those people who defended the independence, sovereignty, and territorial integrity of Ukraine and took direct part in the antiterrorist operation, ensuring its implementation, and were directly in the areas of such an operation, including: (1) the servicemen (reservists, military persons) of the Armed Forces Ukraine, the National Guard of Ukraine, the Security Service of Ukraine, the Foreign Intelligence Service of Ukraine, the State Border Guard Service of Ukraine, (2) the persons of ordinary and commanding staff, military, employees of the Ministry of Internal Affairs of Ukraine, the State Guard of Ukraine, the State Service of Special Communications and Information Protection of Ukraine and other established according to the laws of Ukraine's military formations; (3) the employees of enterprises, institutions, organizations, which were involved and took a direct part in the ATO in the areas of its conduction in accordance with the procedure established by law (Пам'ятка..., 2016; Про статус..., 1993; Сьогодні..., 2015).

The access to the social protection system for ATO participants in Ukraine provides the legal status of a participant in combat operations, which have not only ATO participants, but also participants in 
other military operations that are not related to the anti-rhetorical operation in certain areas of Donetsk and Lugansk oblastey (regions). The practice of the granting the status of participant in combat shows the complexity of the legal registration of this status because of the existence of a significant number of bureaucratic procedures. On the one hand, these procedures exist to confirm the presence of a person in combat operations in the area of ATO, and on the other hand, they become the causes of delays in the implementation of social protection measures. That is why the problem of the objective analysis of the practice of the procedure for granting the status of participant of a participant in combat operations and its optimization for those who took part in combat operations in the zone of ATO is actualized.

\subsection{The legislative strengthening of social protection for ATO participants and the efficiency of their social protection}

At the same time, it is quite predictable that there is a rapid development of legislation aimed at the social protection of ATO participants. A number of legislative acts was enacted in Ukraine for the purpose of the legislative strengthening of social protection for ATO participants. They include:

- the foundation of territorial bodies of the State Service of Ukraine for War Veterans and ATO participants (Деякі питання..., 2015);

- the creation of the network of help centers for ATO participants. These centers act as auxiliary bodies of the district state administrations or city councils to ensure the interaction between executive authorities, other state bodies, local governments, volunteer organizations and nongovernmental organizations in solving the issues of treatment, rehabilitation, social protection, social adaptation for ATO participants. The creation of such centers is provided in connection with the execution of the Decree of the President of Ukraine (Про внесення зміни до Указу..., 2015);

- the approval of regional and district programs of social support for ATO participants and their families financed from regional or district budgets This financing covers such activities as: the provision of ATO participants with technical and other means for rehabilitation, the provision of one-time targeted financial aid for the persons accompanying ATO participants for treatment in medical institutions and for payment of their temporary residence, the purchase of the houses for the deceased servicemen's families who took direct part in the antiterrorist operation and for the invalids of the 1st and 2nd group from the number of military personnel, who participated in the specified operation, and need improvement of living conditions, the provision of onetime targeted financial aid to the servicemen who take (took) direct part in the anti-terrorist operation for the compensation of expenses which connected with the development of documents of land tenure for land allocation for individual housing construction, private peasant farming, horticulture, gardening, the compensation for the cost of housing and communal services, solid fuels and liquefied gas to the members of ATO participants' families, the sanatorium and resort treatment for ATO participants, the social support for ATO participants' families, the provision of necessary social services for ATO participants and their families, the providing free passage in public transport and suburban railways for ATO participants, etc;

- the provision of free comprehensive food for students of general educational institutions from the number of ATO participants' children, the coverage of the events aimed at supporting the members of ATO participants' families in the mass media, the ensuring the burial of deceased ATO participants with payment of appropriate compensation to the deceased ATO participants' families;

- the improvement of the mechanism of using budget funds for social and professional adaptation of ATO participants, namely, the extension of the function of procuring such services by district social security bodies (Про внесення змін до Порядку..., 2015);

- the improvement of the mechanism of prosthetics of ATO participants abroad and the provision of the opportunity for the prosthetics of ATO participants by products of increased functionality using the brand new technologies in Ukraine (Про внесення змін до постанов..., 2014);

- the provision of accommodation and food for ATO participants during the implementation of measures for their psychological rehabilitation (Про затвердження Порядку..., 2017);

- the development of the mechanism for reimbursement to ATO participants of travel expenses to rehabilitation institutions for psychological rehabilitation and back (Про затвердження Порядку виплати..., 2016);

- the payment of compensation to employers of average earnings for workers called to military service during the mobilization (Про військовий обов'язок..., 1992; Кодекс законів..., 1971);

- the payment of financial aid for the servicemen discharged from military service (Про затвердження Порядку..., 2015); 
- the enrollment of time of military service it to a special period of length of service which gives the right to apply for a retirement pension on preferential terms (Про внесення зміни до статTi 8..., 2015);

- the appointment from January 1, 2015 of pensions in case of loss of breadwinner to family members of servicemen who died as a result of injuries, contusions or mutilation received during the defense of the Motherland, fulfillment of other duties of military service (official duties) (Про внесення зміни до статті 36..., 2014; Про внесення зміни до статті 37..., 2014);

- the establishment of the compulsory free psychological, medical and psychological rehabilitation for ATO participants at the appropriate centers with the reimbursement of the cost of passage to these centers and back after performing missions in combat conditions (Про внесення зміни до статті 11..., 2015).

The significant number of state measures on legislative strengthening of social protection for ATO participants is evident. At the same time the questions on the effectiveness of the distribution of funds of the state and local budgets allocated by law to strengthen the social protection of ATO participants and questions on the receiving by each ATO participant the social aid and social services, that they need, have arose. Today, there are official reports from the Ministry of Social Policy of Ukraine and the Ministry of Defense of Ukraine on these questions. In addition, the regional and national programs of social protection for ATO participants contain separate indicators of efficiency, but as a rule they are highly generalized and monitored by central or local authorities mostly only formally. This situation croped up due to the fact that a significant part of the legislation on social protection of ATO participants and relevant state programs began to be created at the end of 2014 - early 2015 years, and there is no yet practical tool to fully evaluate the efficiency of the state measures of social protection of ATO participants. That is why, in our opinion, for answering this questions the is the certain need to develop and implement such tools as:

- the evaluation of the efficiency of national and regional programs of social protection of ATO participants;

- the evaluation of the efficiency of expenditures from local and state budgets intended to strengthen social protection of ATO participants;

- the evaluation of the quality of social services provided to ATO participants.

Nowadays, the term "efficiency" as an economic category is a rather complex and multi-faceted concept. It is customary to define it using elements such as a productivity, a resultivity, and an economy. A productivity is the ratio between the results (output of production, providing of services, performance of works) and the used resources (financial, material, labor resources). A resultivity is the degree of correspondence of actual results and planed results. An economy is the achievement of projected goals for the smallest amount of funds or obtaining a much better result for the same amount of money (Радіонов, 2013). National and regional programs of social protection of ATO participants, governmental expenditures on social protection of ATO participants, provision of social services to them are aimed at providing a certain social effect, which can be considered both as a goal and as a result.

The evaluation of social programs is a procedure for measuring their direct effects, efficiency, and possible long-term effects (Лібанова et al. (eds.), 2010). An overall evaluation of the efficiency of any social program can be determined in the following areas:

- the assessment whether there has been an improvement of the situation identified as a the problem situation at the beginning of the development of a program (the state of the target group);

- the assessment of the degree of achievement of goals (Макарова, 2015).

The following algorithm can be used to evaluate the efficiency of state regional programs of social protection of ATO participants:

1. The determination of the key indicators that characterize ATO participants' social and economic state in the region at the beginning of the program. Such indicators, depending on the purpose of the program, may include:

- the assessment of the state of health (physical and psychological) of ATO participants which is covered by the program, by doctors and by these ATO participants themselves;

- the indicators showing the material status of ATO participants' families: the presence of their own housing, the number of working family members, the availability of benefits for payment of utility bills and problems with their payment, the full board, the availability of the clothing in accordance to the season and necessities, the availability of necessary furniture and home appliances for living, the family's ability to pay for rest and attend cultural events;

- the indicators showing the state of ATO participants on the labor market: the, provision of the workplaces for the ATO participants, who have returned from the ATO zone, the ratio of ATO 
participants' wages with average wage in the region, the participation of unemployed ATO participants in free and training and advanced training,

2. The finding out ATO participants' needs in measures of social protection in a certain region in accordance with the specified indicators. The content of the measures and their number is determined at this stage.

3. The comparison of the relevant indicators at two points: immediately prior to the start of the program and immediately after its completion, and analysis of the ATO participants' need for social protection measures in a specific region after the finishing of a program.

4. The identification of possible medium and longterm effects from the outcome achieved as a result of the implementation of the program.

The other algorithm is appropriate to evaluate the efficiency of the national social protection programs for ATO participants:

1. The determination of the main indicators that characterize the state of social protection of ATO participants in Ukraine. These indicators are: the ratio of the number of ATO participants who applied to the relevant authorities in connection with the need of various social protection measures and the number of participants ATO for whom these measures are implemented, the degree of solving the ATO participants' problems by applying a certain measure of social protection (for example, the providing free pass to the medical institution in another region of Ukraine for ATO participants and persons accompanying them for treatment completely solves the problem of ATO participants' inability to obtain the necessary treatment due to the absence of the appropriate institution at the place of ATO participants' residence), the average processing time of the application and the decision making on the implementation of social protection measures for the ATO participants in the institution of social protection system.

2. The assessment of changes in the indicators of the state of social protection of ATO participants caused by the action of the program as the difference between the values of the main indicators that characterize the state of social protection of ATO participants in Ukraine and were recorded in the absence of a relevant national program and the values of these indicators in different periods of the program's operation.

3. The comparison of the values of the indicators in two sets that are the group of the ATO participants, which was included in the program and the control group of ATO participants. If the score shows the same changes in both sets, this may indicate the effect of not programmatic, but any other factors that require separate study.

4. The identification of possible medium and longterm effects from the outcome achieved as a result of the implementation of the program.

The evaluation of the efficiency of governmental expenditures by its economic essence makes it possible to determine how effective and rational are the activities and behavior of spending units in an effort to achieve maximum results from the state, and above all, budget resources (Радіонов, 2013). In our opinion, the evaluation of the efficiency of governmental expenditures on social protection for ATO participants can be achieved by implementing the following algorithm:

1. The definition of the basic articles of expenditures for social protection of ATO participants (for example, the improvement of health, the legal services, the compensation of the cost of solid fuel and liquefied gas, the compensation of the cost of travel in public transport, the procurement and delivery of food products).

2. The definition of the indicators characterizing the structure of necessary resources for the implementation of basic articles (for example, the amount of certain material resources that necessary for the implementation of the article, the number of institutions in which ATO participants can receive social services, the number of employees that necessary for the implementation of the article, the necessary equipment and its quantity).

3. The determination of the expected social effects from the implementation of expenditure article (in particular, the improving of most ATO participants' health, the improving of the ATO participants' families' financial state etc.), the choice of the indicators that must demonstrate identified effects and the setting the target values for these indicators (for example, 85\% ATO participants' families are provided with their own housing).

4. The choosing the method for analyzing of the ratio of resource indicators and achieving of a social effect from the implementation of articles expenditure. The methods that can be used in this case are:

- the comparative analysis, which means the comparing of the results achieved in prior years with the target values;

- the factor analysis, based on the influence of factor changes (in particular, the increase or the decrease in the expenditure of article) on the result; 
- the analysis of the data package, which investigates the ratio of resources and results in terms of the maximum efficiency achieved by the most progressive spending implementers.

The evaluation of the quality of social services granted to ATO participants is intended to provide the objective results of the activities of state and non-governmental organizations that provide social services to this category of citizens. Basing on the results of the evaluation of the quality of social services provided to ATO participants, the state will be able to formulate a certain regulatory policy, constantly taking measures to improve the quality of social services. Such an evaluation should include three main elements: the assessment of the quality of social services by ATO participants themselves, the assessment of the quality of social services by employees of organizations providing social services to ATO participants, the assessment of the adequacy of the resource provision necessary for the provision of services by employees of organizations providing social services services to ATO participants and by the representatives of the Ministry of Social Policy of Ukraine. In this case, particular attention should be paid to the judgments of the ATO participants about the quality of social services for them, since these judgments accurately express the degree of satisfaction of this category's needs. In general, the involvement of social service users into evaluation of social services is generally recognized as a progressive practice. The main criteria for assessing the quality of services by ATO participants and by employees of the organizations that provide them with social services are: the timeliness of receiving a service by an ATO participant, the territorial and financial availability of the service to him or her, the degree of satisfaction of the ATO participant's needs as a result of receiving the service, professional level of service. The assessment of the adequacy of the resource provision necessary for the provision of services by the employees of the organizations and the representatives of the Ministry of Social Policy of Ukraine is expressed in the following criteria: the sufficiency of financial, personnel and material resources to provide services, the quality of equipment.

The practical implementation of the evaluation of the quality of social services for ATO participants is carried out by means of a questionnaire, where each of the above criteria corresponds to a certain question of the questionnaire. The abundance of judgments expressed by respondents is framed into an integral assessment, which has a hierarchical structure. The lowest element of the structure is one response to a specific aspect of a particular service, and the highest one is the integral assessment of the quality of all social services provided to ATO participants by a specific organization. The complexity of data formalization in this case is solved by involving the mathematical apparatus of fuzzy sets.

The proposed tools of evaluation are the promising measures in terms of ensuring the effectiveness of social protection of ATO participants, since it makes it possible to obtain objective information on the shortcomings and achievement of the state policy on social protection of ATO participants. The Ministry of Social Policy of Ukraine or a joint commission consisting of representatives of the Ministry of Social Policy of Ukraine, local authorities, state and non-governmental organizations providing social services to ATO participants may assess the efficiency of state programs of social protection and quality of social services for ATO participants. The evaluation of the efficieny of the gorvernmental expenditures on the social protection of ATO participants can be made by the Ministry of Finance of Ukraine together with the Accounting Chamber of Ukraine. It should be noted that the Accounting Chamber of Ukraine, having started its work in 1997, today plays an important role in ensuring the financial control of social programs. The Accounting Chamber of Ukraine is a permanent body of external financial control. Since it's establishment this body have been identified many offenses of the regarding of the use of budgetary funds at the level of central and local authorities. The materials about identified regardings are transmitted to the prosecutor's office to take appropriate measures (Макарова, 2015). Consequently, the combination of the efforts of the Accounting Chamber of Ukraine and the Ministry of Finance will have a real positive impact on the efficiency of expenditures on social protection of ATO participants.

\subsection{The funding of social protection for ATO participants in Ukraine within the structure of financing of social protection of the population}

In many countries, there are problems associated with a lack of financial resources that are needed to cover all social programs. There is no exception concerning the questions of financing of the social protection for ATO participants. Despite the great interest of society, Ukrainian science and practice, there is a lack of attention to the question of the role and importance of state funding of social protection for ATO participants and their families, the use of budget resources and local budgets for these purposes. The financial provision of social protection for ATO participants can be described as extremely high degree of state participation, weak participation in it's 
functioning of institutes of civil society and especially of the population itself; the abundance and unsystematic existing of legal acts regulating the activities of social protection bodies of the population; lack of funds in budgets of all levels for financing activities in the field of social protection (Горбулін et al. (eds.), 2015).

Today, more than a quarter of expenditures of budgets of different levels (state and local budgets, funds of social insurance funds and employers, funds of non-profit institutions serving households (NGOs), donor funds (foreign aid)) is directed to finance social protection of population. It is therefore necessary to evaluate these costs, including their share in the aggregate expenditures of the Consolidated Budget of Ukraine and the gross domestic product (GDP). Social protection expenditures over the period from 2014 to 2016 year increased almost twice and play a significant role in the expenditure structure of the Consolidated Budget of Ukraine (26.4\%-30.9\%) and GDP (22.2-20.5\%) (Бюджет..., 2017).

Expenditures on social protection of war and labour veterans, including ATO participants, in Ukraine in 2016 year compared to 2014 year increased 1.5 times (by 2.3 billion hrn) to 6976.5 million hrn, but this is a slight increase, since the share of the respective expenditures in the total expenditures on social protection-3.4-2.7\%, in the expenditures of the Consolidated Budget of Ukraine - only 0.9-0.8\% (Бюджет..., 2017).

The limited funds the state allocates to provide benefits to servicemen and the war veterans are pulverized among the persons, who have benefits, which not only prevents from solving the problems of their social protection, but also generates a social dissatisfaction (Горбулін et al. (eds.), 2015). At the same time, over the next few years, the need to further increase these expenditures will be maintained, because if the they are insufficient, there is a risk of rising social pressure in the country.

The comparative analysis of the costs on social protections, presented as a share of gross domestic product (GDP) in Ukraine and the EU member states for 2011-2014 years, indicates a significant differentiation of these indicators (more than twofold). In 2014, the countries with the highest ratio of social protection expenditures to GDP - France (34.3\%), Denmark (33.5\%), Finland (31.9\%) and the Netherlands (30.9\%) - spent twice as much on social goals (increase of expenditures by $0.7-3.0$ percentage points $(p c t))$ than the four countries with the lowest values of this ratio (reduction of expenditures by $0.7-3.0$ pct): Latvia (14.5\%), Lithuania (14.7\%), Romania (14.8\%) and Estonia (15.1\%). In Ukraine, this figure was $22.2 \%$ (a significant decrease by 1.0 pct) (in 2015 - 20.5\%, which corresponds to a critical reduction of $2.7 \mathrm{pct}$ ), in Poland - 19.0\% (insignificant increase by 0.3 pct) (Національні рахунки..., 2017).

It should be emphasized that there is a paradoxical situation in field of the financing of social protection ATO participants. It looks like this: the expenditures on social protection of ATO participants are only a part of the expenditures on social protection of war veterans, labor veterans and ATO participants; which in their turn is only a minor part of the total social protection expenditures. This condition exacerbates the issue of sufficiency and efficiency of public expenditures on social protection of ATO participants. To solve these issues, firstly, the above-mentioned evaluation of the efficiency of public expenditures on the social protection of ATO participants should be introduced and the division of combatants into separate categories together with the provision of an additional financial guarantee for ATO participants should be done.

\subsection{The providing of housing for ATO participants}

The separate direction for strengthening of the social protection of ATO participants should be the creation of an effective mechanism for solving their housing problems (Про внесення змін до порядків..., 2017; Уряд вирішує..., 2017). АТО Participants have the right to extraordinary (primary) provision of housing. The accounting of citizens, distribution and provision of housing belonging to communal property belongs to the competence of local selfgovernment bodies.

In 2015-2016 years, ATO participants and their families could use such budget housing programs as «Субвенція 3 державного бюджету місцевим бюджетам на будівництво (придбання) житла для сімей загиблих військовослужбовців, які брали безпосередню участь в антитерористичній операції, а також для інвалідів I-II групи з числа військовослужбовців, які брали участь у зазначеній операції, та потребують поліпшення житлових умов» ("State budget subvention for local budgets for the construction (purchase) of housing for the families of the fallen servicemen who took direct part in the anti-terrorist operation, as well as for disabled persons of groups I-II from military personnel who took part in the specified operation and need improvement of living conditions"), «Комплексна програма забезпечення житлом військово-службовців, осіб рядового і начальницького складу, посадових осіб митної служби та членів їхніх сімей» ("Comprehensive Program for providing housing for servicemen, persons of ordinary and 
commanding personnel, customs officials and their family members"), «Забезпечення житлом осіб, які брали безпосередню участь в антитерористичній операції та / або у забезпеченні її проведення і втратили функціональні можливості нижніх кінцівок» ("Housing for persons who took direct part in the anti-terrorist operation and/or its implementation and lost functionality of the lower extremities").

Along with the existence of these programs in the country, there is a significant need for funds for their implementation and the significant number of people from ATO participants who need the improvement of living conditions. The total need for funds for the realization of the right of these individuals to receive housing is 15 billion hrn. By of October 1, 2016 year, there were 31,576 people in the queue for improving of living conditions. Among them are: 4,607 war invalids, including those who participated in the antiterrorist operation; 14,693 participants in combat operations, including ATO participants; 3,419 participants of the war, including ATO participants; 8,857 servicemen discharged from the reserve (Про Рекомендації ..., 2017).

It is obvious that the problem of providing ATO participants with housing is extremely acute. The authors (Горбулін et al. (eds.), 2015, p. 196) note: "For today, there are many cases when servicemen carry out their patriotic duty to the state, while their families do not have proper housing, dwell in dormitories or rent houses on a commercial basis. There is the «Comprehensive Program for providing housing for servicemen, persons of ordinary and commanding personnel, customs officials and their family members» in Ukraine already for a long time. However, its efficiencyy as an instrument for resolving housing problems of military personnel is extremely low as a result of chronic underfunding". At the same time, there are some positive steps, for example, the allocation of 1140.5 million of hrn. from the state budget in 2015 year for the construction and purchase of housing for servicemen of the Armed Forces of Ukraine in order to create an opportunity for the Ministry of Defense of Ukraine to build and to receive over 3 thousand apartments (Горбулін et al. (eds.), 2015).

An other state measures are also taking place to provide housing for ATO participants. In 2015-2016 years, at the expense of the budget program «Субвенція 3 державного бюджету місцевим бюджетам на будівництво (придбання) житла для сімей загиблих військовослужбовців, які брали безпосередню участь в антитерористичній операції, а також для інвалідів I-II групи з числа військовослужбовців, які брали участь у зазначеній операції, та потребують поліпшення житлових умов»
("State budget subvention for local budgets for the construction (purchase) of housing for the families of the fallen servicemen who took direct part in the anti-terrorist operation, as well as for disabled persons of groups I-II from military personnel who took part in the specified operation and need improvement of living conditions") in accordance with the norms of the Procedure for payment of cash compensation for getting living quarters for family members of the fallen soldiers who took a direct participation in the anti-terrorist operation, as well as the disabled persons of groups I-II from the number of military personnel participating in the operation, monetary compensation was paid for self-purchase of 1255 flats (638 and 617 respectively by years) of the aforementioned category in all regions of Ukraine for the total amount of 783 million hrn (367 and 416 million hrn respectively) (Питання забезпечення житлом..., 2016). The condition for the use of funds from the budget program «Забезпечення житлом осіб, які брали безпосередню участь в антитерористичній операції та / або у забезпеченні іï проведення і втратили функціональні можливості нижніх кінцівок» ("Housing for persons who took direct part in the anti-terrorist operation and/or its implementation and lost functionality of the lower extremities") is the purchase of housing by executive authorities at the local level. In 2015-2016, 101 dwelling units (48 and 53 units respectively by years) were purchased for the aforementioned category of persons, whose cash expenses amounted to 73.3 million hrn (32.6 and 40.7 million hrn respectively by years) (Про Рекомендації..., 2017).

The available official static data is not enough to conclude on the percentage of those ATO participants who really needed the providing of housing or the improving housing conditions, received a new home. There was no scientific research on this issue either. The one thing is clear: taking into account the existence in Ukraine of a long-term general problem of providing housing to the population, this percent can be quite significant. However, the given data demonstrate the growing of the state attention to the problem of providing housing for ATO participants and the steps taken to solve this problem.

We believe that the following promising measures can be realized in the future to find out the solution of the problem of providing ATO participants with housing:

- the development and the implementation of a special housing program for ATO participants, that could be funded not only by the state, but also by non-governmental organizations and private investors; 
- the provision of a privileged right for ATO participants' children to receive a youth loan through the State Fund for the Promotion of Youth Housing;

- the providing of the servicemen who have signed a contract for service in the area of ATO the warrants on official apartments, which become their property upon the termination of the contract and fulfillment of its conditions;

- the increase of the amount of benefits for payment of the cost of housing and communal services to combatants in the ATO area.

\subsection{The providing of social services for ATO participants}

An important issue of social protection of ATO participants is to provide them with social services. ATO participants receive most of state social services in territorial centers of social services, centers of social services for the family, children and youth, district labour and social protection departments, employment centers of the State Employment Service of Ukraine, social, psychological and medical rehabilitation centers of the Ministry of Social Policy of Ukraine. Some social services to ATO participants can be provided by health resort facilities of the Ministry of Health of Ukraine. In addition, in July 2017, a Centre for social, medical and psychological services to participants in hostilities, ATO participants and members of their families was opened in Sumy, the activities of which are aimed exclusively at this category of social service recipients. The Centre has 3 structural units: a department of medical and social support; a department of social psychological and pedagogical services; a physiotherapy department (Положення про комунальну установу..., 2017).

In total, 100,168 families of ATO participants with 80,847 children needed social services in the country in 2016. As a result of providing social services for ATO participants in 2016 (Соціальний звіт..., 2017):

- 47,200 people received psychological support and rehabilitation;

- 21,900 people received legal aid;

- 18,400 people received humanitarian aid;

- almost 26,000 people received a land plot;

- 726 families were provided with housing;

- 4,000 families, including 387 persons with disabilities are covered with social support.

The major areas of providing social services for ATO participants are health resort treatment to the victims of the anti-terrorist operation, psychological rehabilitation and social and professional adaptation of the participants in the anti-terrorist operation. At the same time, there is cooperation between the state and non-state sectors. The period of 2015-2016 was characterized by the intensification of the development of each of these areas and increase in the number of ATO participants who managed to receive social services. Let us consider the state of each of these areas.

\subsection{The providing of health resort treatment for the victims of the anti-terrorist operation and their family members}

Participants of ATO (combatants and disabled war veteran) have the right to get free health resort treatment. In accordance with the Procedure for using funds provided by the state budget for the provision of victims of ATO by health resort treatment (Дорожня карта щодо забезпечення..., 2017; Про внесення змін до Порядку..., 2016; Про затвердження Порядку використання..., 2017), 7,848 ATO participants were rehabilitated in accordance with the relevant budget program in 2015-2016, including 275 disabled war veterans (Соціальний звіт..., 2016, 2017).

Since March 2017, the authority to the purchase of vouchers for the ATO participants has been transferred at the local level and the opportunity to independently choose a sanatorium for treatment was given to the ATO participants. Today, the provision of vouchers by the victims of the anti-terrorist operation will be carried out within the allocated funds in proportion to the number of persons taken into account to provide sanatorium treatment, in accordance with the agreements concluded by the structural departments on social protection of the population or social protection bodies with sanatorium and resort facilities, having a license for the conducting economic activity in medical practice and accreditation not lower than the first category, and by ATO participants.

The bodies of social protection of the population provide ATO participants with free vouchers for treatment in sanatorium establishments in accordance with the legal procedure (Про затвердження Порядку використання коштів..., 2017) according to medical recommendations in order of priority with the receipt of vouchers.

The total expenditures from the State Budget in 2016 year to provide the victims of the antiterrorist operation with the sanatorium treatment within the budget program «Заходи із психологічної реабілітації, соціальної та професійної адаптації учасників антитерористичної операції та забезпечення постраждалих учасників антитерористичної операції санаторно-курортним лікуванням» ("Mеаsures for the psychological rehabilitation, social and professional adaptation of ATO participants and provision of the victims of the antiterrorist operation 
with sanatorium treatment") amounted to 22.1 million hrn. In 2015 year these expenditures were 22.5 million hrn. Besides, in 2015 year 3646 ATO participants received treatment in sanatorium and resort institutions of the Ministry of Social Policy of Ukraine and 2179 ATO participants got treatment in sanatorium and resort institutions of the Ministry of Defense of Ukraine (Про Рекомендації..., 2017).

The recreation and rest of ATO participants' children are carried out at the expense of state and local budgets, the funds of enterprises, institutions and organizations, trade unions and funds, voluntary contributions from legal entities and individuals, and other sources. Children from 7 to 18 years are sent to children's health and recreation institutions at the expense of the state budget if the the voucher was not provided to the child this year at the expense of local budgets. The local authorities are involved in the procurement and distribution of children's vouchers within the administrative-territorial units. The Ministry of social policy of Ukraine byes the vouchers to the state enterprise «Український дитячий центр «Молода гвардія» (“Ukrainian Children's Center "Young Guard") for children of preferential categories. The vouchers to the children's health and recreation establishments may be provided free of charge or with a partial payment, when 20,30 or 50 percent of the cost of a vouchers are paid at the expense of parents (persons those who replace them) or other sources not prohibited by law (Інформація про оздоровлення..., 2016).

131,000 children of combatants and internally displaced persons were provided with health improvement and recreation (more than 4 million children were rehabilitated $(3.3 \%$ of the total number of children who improved their health). In the child centers, «Молода гвардія» ("Young Guard") and «Артек» ("Artek") in 2016 more than 15,000 children of the groups entitled to special benefits improved their health, including 1,450 children (9.6\%) from the localities situated on the line of collision.

For 2015-2016 years, 9,840 children were rehabilitated abroad, in particular, in Argentina, Bulgaria, the United Kingdom, Greece, Georgia, Spain, Israel, Italy, Latvia, Lithuania, Moldova, the Netherlands, Germany, Poland, Portugal, Romania, Serbia, Slovakia, Slovenia, the USA, Turkmenistan, Turkey, Hungary, Finland, France, Croatia, Switzerland, Sweden, Scotland, including: 831 children of combatants (8.4\% of children who improved their health abroad); 1,553 children of internally displaced persons (15.8\% respectively) (Соціальний звіт..., 2016, 2017). In the summer of 2017 year, Ukrainian children from ATO participants' families rested for 10 days in the recreation camp of the Ministry of Education and
Culture of the Republic of Cyprus, located in the mountain village of Prodromos (Інформація щодо відпочинку..., 2017), 19 children aged from 10 to 15 years from Zhytomyr region rested in town Krosno in Podkarpackie Voivodship of Republic of Poland (Діти із сімей ..., 2017).

Consequently, in order to form and ensure implementation of the state policy in the field of health improvement and rest of ATO participants and their family members in Ukraine, it is necessary to carry out the following measures:

- the creation of an accessible and efficient market of health and recreation services;

- the preservation and the development of a network of health and recreation institutions, including the institution for children;

- the of providing training of the stuff for the implementation of health and recreation activities, including the activities for children (Оздоровлення..., 2017);

- the creation of the mechanisms for economic stimulation, lending and targeted financial support for institutions that provide health care and recreation, including the activities for children;

- the creation of the State register of health improvement and recreation institutions, including the institution for children, in order to prevent their liquidation, bail transfers, re-profiling, and use for other purposes except treatment and recreation;

- the development and approval of state social standards in the field of treatment and recreation activity.

\subsection{An employment of participants of the anti- terrorist operation}

The status of the unemployed by the October 1, 2017 year had 11.8 thousand unemployed ATO participants. On average, in Ukraine, the share of ATO participants among all registered unemployed was $4 \%$, the largest share of unemployed ATO participants was in Khmelnytsky (6\%) and Vinnytsia (7\%) regions (Щодо надання послуг..., 2017).

In accordance with the Law of Ukraine (Про внесення зміни до статті 14..., 2016), combatants who took a direct part in ATO and its implementation were included in the list of categories of citizens with additional guarantees in the promotion of employment, the employment of which is mandatory in the framework of employment places quota (Президент підписав Закон..., 2016; Як допомогти..., 2017).

To promote employment and social integration of ATO participants, the State Employment Service provides them with a full range of services through organizing community service, vocational guidance, 
vocational training (vocational training or retraining, further training), provision of a voucher.

During 2015 - September 2017, 108,000 unemployed from the number of the demobilized servicemen who participated in the ATO took advantage of the services of the State Employment Service. Vacancies were selected and a job was offered to each participant of ATO. With the assistance of the State Employment Service in 2015 - September 2017, 22,400 participants of ATO were employed. Of the total number of the employed ATO participants in 2016, 135 people are recruited for newly created jobs with compensation of a single payment to employers. From beginning of the 2015 year till the September of 2017 year 2,500 ATO participants received one-time unemployment aid. The average unemployment aid of such persons by of October 1 , 2017 year amounted to 3,861 hrn. and the average amount of aid for all categories of the unemployed was 2,033 hrn. In addition, 8,700 ATO participants received additional material support during the search for their main place of employment by engaging in temporary and civic and other work (Щодо надання послуг..., 2017).

One third of the unemployed ATO participants is employed at the place of workers for servicing, operating and controlling the work of equipment and machinery; every fifth of the unemployed ATO is employed at the place of skilled workers with a tool; $15 \%$ of the unemployed ATO participants are employed at the working places that do not require special training; $12 \%$ of the unemployed ATO participants are employed in the sphere of trade and services, every tenth of the unemployed ATO participants is employed in the place of managers. According to the types of economic activity one can see that $29 \%$ of the unemployed ATO participants are employed in agriculture, forestry and fisheries; every fifth of this category is employed in the processing industry, $13 \%$ - in wholesale and retail trade; $8 \%$ - in public administration and defense. To increase the competitiveness of the given category of the unemployed on the labour market and accelerate their employment, 6,700 people got vocational training by the referral of the State Employment Service. Each fourth ATO participant has only secondary education, and the suitable work for this category of persons is not requiring special training and, as a rule, is paid for the minimum amount (Щодо надання послуг..., 2017).

To ensure the awareness of the demobilized ATO participants and their families about the social services of the State Employment Service, regional employment services, informational corners with materials have been created, special seminars and trainings on modern methods aimed at their social adaptation to the labor market are held, a road map and instructions are developed, actions with military units and military registration and enlistment offices for timely informing about the conditions of registration at the employment agency, providing unemployment benefits and social services to find employment are coordinated; information on the services of the State Employment Service for demobilized ATO participants in military registration and enlistment offices is presented (Дорожня карта..., 2017; Пам'ятка..., 2016; Про внесення змін до Концепції..., 2017).

\subsection{The psychological rehabilitation and the social and professional adaptation of ATO participants}

In 2015-2016, services for psychological rehabilitation were provided by 15 rehabilitation institutions (various forms of ownership), with which the State Service for War Veterans and Anti-Terrorist Operation Participants concluded respective service contracts. Totally, 11,683 ATO participants from different regions of Ukraine were provided with services for psychological rehabilitation during this period (Про внесення змін до Порядку..., 2015; Соціальний звіт..., 2016, 2017).

At the same time, at the regional and local level, psychological rehabilitation services for ATO participants are provided by ordinary medical, health resort facilities, their structural divisions as well as by public organizations (Актуальність створення..., 2017; Громадський сектор..., 2017; Про схвалення Концепції..., 2017; Роз'яснення Служби..., 2015; Уряд схвалив ..., 2017).

The State Service for War Veterans and AntiTerrorist Operation Participants includes 5 centers for social and psychological rehabilitation of the population located in urban settlement Ivankiv, towns Boiarka, Borodianka, Slavutych of Kyiv oblast and Korosten of Zhytomyr oblast. In 2015-2016, the specialists of these centers provided social and psychological services to 15,839 ATO participants and 13,609 members of their families. In 2015-2016, 8,036 participants of ATO received professional adaptation services based on contracts concluded with the population social protection bodies with educational institutions (enterprises, institutions, and organizations, irrespective of the form of ownership). Most of them received the qualification of drivers of motor vehicles of various categories, industry and service sector professions and IT technologies occupations (Соціальний звіт ..., 2017).

In 2017 year, the Cabinet of Ministers of Ukraine adopted by its resolution the Procedure for Organizing Social and Professional Adaptation of the ATO 
Participants (Про затвердження Порядку організації..., 2017; Уряд затвердив..., 2017), which would ensure the following:

- the formation of an effective mechanism for organizing of the restoration of professional skills of ATO participants as an integral part of their social adaptation to the conditions of a civil life;

- the right of ATO participants for education throughout their lives;

- the increasing of the promptness of solving the problematic issues of ATO participants, related to their professional activities and the increasing of their competitiveness on the labor market.

Therefore, in order to solve such important issues as psychological rehabilitation and the social and professional adaptation of ATO participants, it is necessary to apply a unified approach to psychological rehabilitation and to create the appropriate clubs of ATO participants and ATO veterans which would be aimed at solving, in particular, issues of the psychological assistance and social adaptation of fighters, the improvement of co-ordination of actions of state bodies and institutes, the integration of demobilized ATO participants in society (Сьогодні..., 2015).

\subsection{The non-governmental social services for ATO participants}

Non-governmental organizations also provide social services to ATO participants. Their work improves the efficiency of social protection for ATO participants. Non-state organizations mainly work at the primary level, and therefore their activities better take into account the ATO participants' needs in assistance and social services. It is possible to distinguish the following areas of work of non-governmental organizations in providing social services to ATO participants:

- the assistance in the evacuation of wounded ATO participants from the ATO zone;

- the organization and support of treatment of wounded in medical institutions of Ukraine;

- the organization of sending seriously wounded ATO participants for treatment and rehabilitation to foreign clinics in Europe and in the world;

- the legal advice and legal assistance (in particular, with the determination of the status of ATO participant, protection of rights, etc.);

- the assistance in providing housing for ATO participants and in providing them with a plots of land;

- the assistance in liberation from captivity;

- the collection for ATO participants of humanitarian aid (clothing, food, toiletry, medicines) and its delivery to the zone of ATO;
- the assistance in arranging of everyday life for ATO participants;

- the collection of funds for the purchase of body armors and another equipment necessary for the Armed Forces of Ukraine;

- a psychological rehabilitation, integration measures, social support;

- the assistance in the employment for ATO participants;

- the organization of leisure for ATO participants and their families.

It can be noticed that there is a significant diversity in terms of the status of non-governmental organizations that provide social services for ATO participants in Ukraine. Today one can select the following types according to the status of such organization (Горемикіна, 2016):

- officially registered volunteer organizations;

- officially registered public organizations and public associations;

- officially registered charitable foundations and charitable organizations;

- officially registered associations of volunteer organizations;

- officially registered associations of public organizations;

- individual activity of a volunteer without participation in organizations;

- Civic Initiatives and Civic Platforms;

- groups of citizens (active group, distributed in social networks) that actually provide assistance to internally displaced persons and ATO participants, but they are not officially registered organizations and do not use the name "volunteers".

Some of these organizations specialize in providing social services and assistance to ATO participants who have returned from the ATO zone, while some concentrate on assisting the Armed Forces of Ukraine and ATO participants in the ATO area. The sources of information about the work of such organizations are their official sites, their official pages in social networks, the media, some "social advertising". The detailed reports on financial revenues, expenditures and implemented projects are often placed on sites of non-governmental that provide social services for ATO participants. In addition, there is the «Єдиний реєстр волонтерських організацій» ("Unified Register of Volunteer Organizations") on the official website of the Ministry of Labor and Social Policy of Ukraine, and there is the «Єдиний реєстр громадських організацій» (“Unified Register of Public Organizations") on the website of the Ministry of Justice of Ukraine. However, not all organizations are officially registered and therefore there is no general list of organizations providing social 
services to ATO participants. Among the most wellknown organizations providing social services to ATO participants are «Волонтерська сотня», ("Volunteer's hundred"), «Донбас SOS», ("Donbass SOS"), «Подільска громада» ("The community of Podillya"), «Психологічна кризова служба» ("Psychological Crisis Service"), «Фонд Оперативної Національної Допомоги Діани Макарової» ("Diana Makarova's Fund of Operational National Assistance") - initiative group of activists, «39 жіноча сотня» ("39th female hundred"), the Charitable Foundation «Єдина родина» ("United Family"), «Єдиний волонтерський центр. Чернігів» ("The Unified Volunteer Center. Chernihiv"), the International Charitable Foundation «Шпиталь Майдану» ("The hospital of Maidan"), «Армія SOS» ("SOS Army"), «Всеукраїнська асоціація учасників бойових дій» ("All-Ukrainian Association of Hostilities Participants").

Non-governmental organizations cooperate with the state in the field of providing social services to ATO participants through a social order mechanism. An example of such cooperation can be the activity of the All-Ukrainian Charitable Organization «lнiціатива заради життя» ("Initiative for the sake of life"), which received a social order for social adaptation, crisis and emergency intervention, counseling for demobilized ATO participants and members of ATO participants' families.

It is important to note that some non-state organizations create opportunities for providing ATO participants with social services in ways that are new to the state. In particular, the public Union «Всеукраїнське об'єднання учасників АТО «Українці-Разом!» ("All-Ukrainian Association of ATO Participants "Ukrainians are Together!") within the framework of a unified all-Ukrainian social and legal program for assistance to Hostilities Participants called "Social card of ATO participant" with the support of the State Service of Ukraine for War Veterans and ATO participants, the Ministry of Defense of Ukraine, the National Guard of Ukraine, the Security Service of Ukraine, the State Border Guard Service of Ukraine, socially responsible business offer to ATO participants to receive a social card of ATO participant, which provides the following possibilities to the owner: a free legal support and legal advice, a free medical examination and provision of medical services, a psychological support, some discounts for the purchases in all-Ukrainian trading networks, the participation in educational, recreational and entertainment programs (Всеукраїнське об'єднання..., 2017).

The official data show that social services for ATO participants, both governmental and nongovernmental, cover a significant number of recipients and types of social services. At the same time, qualitative aspects of the work of institutions providing social services to ATO participants are largely left out of the state attention. However, these aspects greatly influence on the solving of the problems which made ATO participant apply in the social protection system. That is why, the use of the above-mentioned tool for evaluating of quality of social services in practice will help to reduce the social vulnerability of ATO participants and their families and prevent the aggravation of difficult situations in the lives of ATO participants and their families.

The extension of the aforementioned practice of social order of social services for ATO participants and their families can be also seen as a promising measure to improve the quality of social services granted to ATO participants and their families. Sometimes this mechanism is called a social contact. The part of the funds allocated for the provision of social services in local budgets after the competition is expedient to transfer for the procurement of these services in non-governmental organizations that have confirmed their ability to provide high-quality service to ATO participants. At the same time, tender procedures should be clear and understandable to all the participants of competition, and after the implementation of the contract, it is logical to establish the evaluating of the quality of provided services. Some non-state organizations have already been working on this scheme, but the social order of services for ATO participants are only beginning to be part of the practice of cooperation between nongovernmental organizations and local authorities. Today, most of the concluded social contracts relate to sanatorium care services, rehabilitation and social adaptation.

\section{Summary}

The held analytical review leads to the conclusion that today Ukraine uses a wide range of social protection measures for ATO participants, which are intended to solve problems of this category and considerable budget funds are allocated for these measures.

However, a new problem field arises. So, a number of important issues are opened to consider. First, the procedure for obtaining the status of a participant in hostilities, without which ATO participant cannot have access to social protection programs, social services, privileges, is a rather complex and time-consuming task. Therefore a certain number 
of ATO participants who actually protect the sovereignty of Ukraine remain not covered by social protection.

Secondly, there is no objective information on effectiveness of solving the ATO participants' problems by the system of social protection in Ukraine and there is no objective information on quality of the social services provided to them by state and non-governmental organizations. Some government organizations, such as territorial centers for social services, carry out internal monitoring and evaluation, but ATO participants represent only a small proportion of the contingent they serve.

Thirdly, the practice of social order, which could become a mechanism for effective cooperation between the state and non-governmental organizations in providing social services to ATO participants, has not yet been sufficiently spread. Non-governmental organizations, which first came to the aid of ATO participants in 2014-2015 years, still work mainly for sponsorship and charity, the state support of such organizations is very limited.

Foruthly, the ATO participants' opinion on the quality and effectiveness of social protection and social services is not systematically studied. We believe that it should be studied separately.

Consequently, the sphere of social protection of the population, including ATO participants and their families, in Ukraine requires the solution of the above-mentioned problems, as well as the improvement of the legislative framework regulating its activities, the improving the of the financing of this sphere, the reduction of administrative expenses, settlement of the number of social benefits which guaranteed by the state to socially vulnerable categories of citizens, the improving of the quality and efficiency of social services, in particular social services provided to ATO participants and their family members, etc. It is also necessary to introduce the evaluation of the efficiency of national and regional social programs for ATO participants and the evaluation of the public expenditures for the social protection of ATO participants.

\section{References}

Актуальність створення сучасної системи реабілітації учасників АТО обговорювали в УКРІНФОРМІ, 2017, [in:] Державна служба України у справах ветеранів війни та учасників антитерористичної операції, http://dsvv.gov. ua/aktualni-pytannya/aktualnist-stvorennya-suchasnojisystemy-reabilitatsiji-uchasnykiv-ato-obhovoryuvaly-vukrinformi.html [28.10.2017].

Алієв О., 2017, Сочіальні гарантії учасникам АТО. Практичні поради, [in:] Державна служба України у спра- вах ветеранів війни та учасників антитерористичної операції, http://dsvv.gov.ua/aktualni-pytannya/ oleksandr-alijev-sotsialni-harantiji-uchasnykam-atopraktychni-porady.html [http://dsvv.gov.ua/aktualnipytannya/dorozhnya-karta-schodo-zabezpechennyasanatorno-kurortnym-likuvannyam-uchasnykiv-ato.html [28.10.2017].

Бюджет України 2016, Статистичний щорічник, 2017, [in:] Міністерство фінансів України, https://www.minfin.gov. ua/uploads/redactor/files/Budget\%20of\%20Ukraine\%20 2016.pdf [23.08.2017].

Ветлинський С.О., 2016, Соціальний захист військовослужбовців в умовах проведення антитерористичної операції, Ефективність державного управління, 4(49), 198-205.

Всеукраїнське об'єднання учасників АТО «Україниі разом!», 2017, Українці разом, http://ukrazom.org/social-card [23.08.2017].

Горбулін В.П., Власюк О.С., Лібанова Е.М., Ляшенко О.М. (eds.), 2015, Донбас і Крим: ціна повернення, Національний інститут стратегічних досліджень, Київ.

Горемикіна Ю.В., 2016, Державні та недержавні соціальні послуги для ВПО в Україні, [in:] Дослідження ефективності факторів зростання конкуренто-спроможності економіки: теорії та пропозичії: збірник матеріалів Всеукраїнської науково-практичної конференції (м. Київ, 25-26 листопада 2016 р.), Видавництво ГО «Київський економічний науковий центр», Київ, 115-118.

Громадський сектор: новий погляд на соціалізацію учасників бойових дій, 2017, [in:] Державна служба України у справах ветеранів війни та учасників антитерористичної операції, http://dsvv.gov.ua/aktualni-pytannya/ hromadskyj-sektor-novyj-pohlyad-na-sotsializatsiyuuchasnykiv-bojovyh-dij.html [08.09.2017].

Деякі питання діяльності Державної служби у справах ветеранів війни та учасників антитерористичної операції. Постанова Кабінету Міністрів України від 15.06.2015 № 395, 2015, Кабінет Міністрів України, http://zakon5.rada.gov.ua/laws/show/395-2015-\%D0\%BF [23.08.2017].

Діти із сімей, які постраждали через бойові дії на Сході України, відправились на відпочинок до Польщі, 2017, [in:] Міністерство соціальної політики України, http:// www.msp.gov.ua/news/13652.html [23.08.2017].

Длугопольська Т., 2016, Історія розвитку законодавства про соціальний захист населення: міжнародний аспект, Актуальні проблеми правознавства, 3, 58-63.

Дорожня карта «Як знайти роботу військовослужбовцям та учасникам ATO», 2017, [in:] Державна служба зайнятості, http://www.dcz.gov.ua/control/uk/index [28.10.2017].

Дорожня карта щодо забезпечення санаторно-курортним лікуванням учасників антитерористичної операчіï, 2017, [in:] Державна служба України у справах ветеранів війни та учасників антитерористичної операціï, http://dsvv.gov.ua/aktualni-pytannya/dorozhnyakarta-schodo-zabezpechennya-sanatorno-kurortnymlikuvannyam-uchasnykiv-ato.html [28.10.2017]. 
Інформачія про оздоровлення та відпочинок дітей учасників АTO, 2016, [in:] Офіційний сайт Херсонської Обласної державної адміністрації, http://khoda.gov.ua/ informaciya-pro-ozdorovlennya-ta-vidpochinok-ditejuchasnikiv-ato [08.09.2017].

Інформачія щодо відпочинку дітей постраждалих внаслідок збройного конфлікту на Сході України, 2017, [in:] Міністерство соціальної політики України, http://www. msp.gov.ua/news/13603.html [08.09.2017].

Каленюк І.С., Котенко Т.М., 2016, Соціальні аспекти розвитку рекреації та туризму в Україні, Демографія та соціальна економіка, 2(27), 89-101.

Ковалевич Д.А., 2017, Видатки місцевих бюджетів на соціальний захист населення, Економічний форум, 2, 280-286.

Кодекс законів про пращю України. Закон України від 10.12.1971 № 322-VIII, 1971, Відомості Верховної Ради України, http://zakon3.rada.gov.ua/laws/show/322-08 [23.08.2017].

Кравченко М.В., 2015, Основні проблеми соціального захисту учасників АТО, Аспекти публічного управління, $11-12,6-43$.

Кучер Г.В., 2016, Державні видатки на соціальний захист крізь призму економічного розвитку, Економічний вісник університету, 30(1), 236-245.

Лаврухін В.В., 2014, Соціальний захист як складова соціальної політики держави: теоретичний аналіз, Ефективність державного управління, 41, 227-233.

Лібанова Е.М., Макарова О.В., Саріогло В.Г., Терещенко Г.І., Черенько Л.М. (eds.), 2010, Якість інформаційного забезпечення сочіальної політики, Дух і Літера, Київ.

Макарова О.В., 2015, Соціальна політика в Україні, Інститут демографії та соціальних досліджень ім. М.В. Птухи НАН України, Київ.

Маліновська О.Я., Рудзінська Р.О., 2013, Суть поняття «соціальний захист» у загальній системі соціальної політики, Вісник Дніпропетровської державної фінансової академії, Економічні науки, 2, 8-14.

Марценюк О.В., 2015, Соціальний захист населення України, Теоретичні і практичні аспекти економіки та інтелектуальної власності, 2(3), 166-170.

Надрага В.І., 2014, Соціальний захист в системі мінімізації соціальних ризиків, Соціально-трудові відносини: теорія та практика, 2, 486-490.

Насібова О.В., 2015, Бюджетні видатки на соціальний захист населення в Україні, Вісник Одеського національного університету, Серія : Економіка, 20.2(1), 155-159.

Національні рахунки соціального захисту (НРС3) у 2015 рочі. Статистичний бюлетень, 2017, [in:] Державна служба статистики України, Київ, http://www.ukrstat. gov.ua/ [23.08.2017].

Огінська А., 2014, Видатки місцевих бюджетів на соціальний захист, Світ фінансів, 4, 103-109.

Оздоровлення та відпочинок дітей, 2017, [in:] Міністерство соціальної політики України, http://www.msp.gov. ua/timeline/Ozdorovlennya-ta-vidpochinok-ditey.html [08.09.2017].

Пам'ятка учасникам АТО. Права, обов'язки та гарантії сочіального захисту, 2016, [in:] Державна служба
України у справах ветеранів війни та учасників антитерористичної операції, http://dsvv.gov.ua/wpcontent/uploads/2017/02/Pamiatka-Uchasnyku-ATO.pdf [08.09.2017].

Питання забезпечення житлом деяких категорій осіб, які захищали незалежність, суверенітет та територіальну цілісність України, а також членів їх сімей. Постанова Кабінету Міністрів України від 19.10.2016 № 719, 2016, Кабінет Міністрів України, http://zakon3. rada.gov.ua/laws/show/719-2016-\%D0\%BF [23.08.2017].

Пільги та гарантії для учасників АТО, 2017, http://dsvv.gov. ua/wp-content/uploads/2015/06/PILHY-TA-HARANTIJiDLYa-UChASNYKIV-ATO-SKAChATY-FAJL.PDF.pdf [29.10.2017].

Положення про комунальну установу «Центр обслуговування учасників бойових дій, учасників антитерористичної операчії та членів їх сімей» Сумської міської ради (нова редакція), 2017, [in:] Сумська міська рада, http://atocentr.sumy.ua/?page_id=578 [23.08.2017].

Президент підписав Закон щодо додаткових гарантій прачевлаштування учасників АTO, 2016, [in:] Державна служба України у справах ветеранів війни та учасників антитерористичної операції, http://dsvv.gov.ua/ aktualni-pytannya/prezydent-pidpysav-zakon-schodododatkovyh-harantij-pratsevlashtuvannya-uchasnykivato.html [08.09.2017].

Про військовий обов'язок та військову службу. Закон України від 25.03.1992 № 2233-XII, 1992, Відомості Верховної Ради України, http://zakon2.rada.gov.ua/laws/ show/2232-12 [23.08.2017].

Про внесення змін до Кончепиії державної системи професійної орієнтації населення. Постанова Кабінету Міністрів України від 09.08.2017 р. № 561, 2017, Кабінет Міністрів України, http://www.kmu.gov.ua/control/uk/ cardnpd?docid=250189789 [23.08.2017].

Про внесення змін до порядків, затверджених постановами Кабінету Міністрів України від 11 лютого 2009 р. № 140 і від 29 лютого 2012 р. № 193. Постанова Кабінету Міністрів України від 20.09.2017 р. № 708, 2017, http://zakon5.rada.gov.ua/laws/show/708-2017$\%$ D0\%BF [28.10.2017].

Про внесення змін до Порядку використання коштів, передбачених у державному бюджеті для здійснення заходів із соціальної та професійної адаптачії учасників антитерористичної операчії (крім військовослужбовців, звільнених у запас або відставку). Постанова Кабінету Міністрів України від 13.10.2015 № 837, 2015, Кабінет Міністрів України, http://zakon2.rada.gov.ua/laws/ show/837-2015-\%D0\%BF [23.08.2017].

Про внесення змін до Порядку використання коштів, neредбачених у державному бюджеті на забезпечення постраждалих учасників антитерористичної операчії санаторно-курортним лікуванням. Постанова Кабінету Міністрів України від 08.08.2016 № 510, 2016, Кабінет Міністрів України, http://zakon5.rada.gov.ua/ laws/show/510-2016-\%D0\%BF [23.08.2017].

Про внесення змін до постанов Кабінету Міністрів України від 23 квітня 2014 р. № 117 і від 1 жовтня 2014 р. № 518. Постанова Кабінету Міністрів України від 24.02.2016 
№ 172, 2016, Кабінет Міністрів України, http://zakon2. rada.gov.ua/laws/show/172-2016-\%D0\%BF [23.08.2017].

Про внесення зміни до статті 11 Закону України «Про соціальний і правовий захист військовослужбовців та членів їх сімей». Закон України від 03.11.2015 № 739-VIII, 2015, Відомості Верховної Ради України, http://zakon3. rada.gov.ua/laws/show/739-19 [23.08.2017].

Про внесення зміни до статті 14 Закону України «Про зайнятість населення» щодо додаткових гарантій у сприянні прачевлаштуванню учасників бойових дій, які брали безпосередню участь в антитерористичній операції, забезпеченні ії проведення. Закон України від 07.07.2016 № 1436-VIII, 2016, Відомості Верховної Ради України, http://zakon3.rada.gov.ua/laws/show/1436-19 [23.08.2017].

Про внесення зміни до статті 36 Закону України «Про пенсійне забезпечення осіб, звільнених з військової служби, та деяких інших осіб». Закон України від 20.05.2014 № 1274-VII, 2014, Відомості Верховної Ради України, http:// zakon5.rada.gov.ua/laws/show/1274-18 [23.08.2017].

Про внесення зміни до статті 37 Закону України «Про пенсійне забезпечення осіб, звільнених з військової служби, та деяких інших осіб». Закон України від 20.06.2014 № 1542-VII, 2014, Відомості Верховної Ради України, http:// zakon2.rada.gov.ua/laws/show/1542-18 [23.08.2017].

Про внесення зміни до статті 8 Закону України «Про соціальний і правовий захист військовослужбовців та членів їх сімей. Закон України від 05.03.2015 № 242-VIII, 2015, Відомості Верховної Ради України, http://zakon5. rada.gov.ua/laws/show/242-19 [23.08.2017].

Про внесення зміни до Указу Президента України від 18 березня 2015 року № 150, 2015. Про додаткові заходи щодо сочіального захисту учасників антитерористичної операчії. Указ Президента України від 05.10.2015 року № 570/2015, 2015, Відомості Верховної Ради України, http://zakon2.rada.gov.ua/laws/ show/570/2015 [23.08.2017].

Про затвердження Порядку використання коштів, передбачених у державному бюджеті для здійснення заходів із психологічної реабілітації учасників антитерористичної операчії. Постанова Кабінету Міністрів України від 12.07.2017 № 497, 2017, Кабінет Міністрів України, http://zakon2.rada.gov.ua/laws/show/4972017-\%D0\%BF/paran8\#n8 [23.08.2017].

Про затвердження Порядку використання коштів, передбачених у державному бюджеті для виплати матеріальної допомоги військовослужбовцям, звільненим з військової строкової служби. Постанова Кабінету Міністрів України від 08.04.2015 № 185, 2015, Кабінет Міністрів України, http://zakon2.rada.gov.ua/laws/ show/185-2015-\%D0\%BF [23.08.2017].

Про затвердження Порядку використання коштів, передбачених у державному бюджеті для забезпечення деяких категорій інвалідів санаторно-курортними путівками, та внесення змін до порядків, затверджених постановами Кабінету Міністрів України від 22 лютого 2006 р. № 187 і від 31 березня 2015 р. № 200. Постанова Кабінету Міністрів України від 01.03.2017 № 110,
2017, Кабінет Міністрів України, http://zakon3.rada.gov. ua/laws/show/110-2017-\%D0\%BF [23.08.2017].

Про затвердження Порядку виплати грошової компенсачії вартості проїзду учасників антитерористичної операції до реабілітаційних установ для проходження психологічної реабілітачії та назад. Постанова Кабінету Міністрів України від 23.08.2016 № 528, 2016, Кабінет Міністрів України, http://zakon2.rada.gov.ua/laws/ show/528-2016-\%D0\%BF [23.08.2017].

Про затвердження Порядку організачії сочіальної та професійної адаптачії учасників антитерористичної операції. Постанова Кабінету Міністрів України від 21.06.2017 р. № 432, 2017, Кабінет Міністрів України, http://zakon2.rada.gov.ua/laws/show/432-2017\%D0\%BF [23.08.2017].

Про Рекомендації парламентських слухань на тему: «Державні гарантії сочіального захисту учасників антитерористичної операчії, Револючії Гідності та членів їхніх родин: стан і перспективи». Постанова Верховної Ради України від 09.02.2017 р. № 1843-VIII, 2017, Верховна Рада України, http://zakon2.rada.gov.ua/laws/show/ ru/1843-19 [28.10.2017].

Про статус ветеранів війни, гарантіїїх сочіального захисту. Закон України від 22 жовтня 1993 року № 3551-XII, 1993, Відомості Верховної Ради України, http://zakon5. rada.gov.ua/laws/show/3551-12 [23.08.2017].

Про схвалення Концепчії Державної цільової програми з фізичної, медичної, психологічноїреабілітачії і сочіальної та професійної реадаптачії учасників антитерористичної операчії на період до 2022 року. Розпорядження Кабінету Міністрів України від 12.07.2017 р. № 475-p., 2017, Кабінет Міністрів України, http://www.kmu.gov. ua/control/uk/cardnpd?docid=250138251 [29.10.2017].

Про утворення Державної служби України у справах ветеранів війни та учасників антитерористичної операчії. Постанова Кабінету Міністрів України від 11.08.2014 № 326, 2014, Кабінет Міністрів України, http://zakon2. rada.gov.ua/laws/show/326-2014-\%D0\%BF [23.08.2017].

Радіонов Ю.Д., 2013, Оцінка ефективності державних видатків, Економіка України, 12(625), 76-87.

Роз'яснення Служби: сочіальна та професійна адаnтація учасників АTO, 2015, [in:] Державна служба України у справах ветеранів війни та учасників антитерористичної операції, http://dsvv.gov.ua/aktualnipytannya/roz-yasnennya-sluzhby-sotsialna-ta-profesijnaadaptatsiya-uchasnykiv-ato.html [08.09.2017].

Соціальний звіт за 2015, 2016, [in:] Міністерство соціальної політики України, Київ, http://www.msp.gov.ua/ timeline/Socialni-zviti-.html [23.08.2017].

Соціальний звіт за 2016, 2017, [in:] Міністерство соціальної політики України, Київ, http://www.msp.gov.ua/ timeline/Socialni-zviti-.html [23.08.2017].

Сьогодні за круглим столом обговорювались актуальні питання допомоги учасникам ATO, 2015, [in:] Державна служба України у справах ветеранів війни та учасників антитерористичної операції, http://dsvv.gov.ua/topnovyny/sohodni-za-kruhlym-stolom-obhovoryuvalysaktualni-pytannya-dopomohy-uchasnykam-ato.html [08.09.2017]. 
Товстиженко О.В., Марченко Н.А., Приходько М.М., 2014, Соціальний захист населення: сутність та проблеми його фінансування, Науковий вісник Чернігівського державного інституту економіки і управління, Серія 1: Економіка, 1, 100-104.

Топішко Н.П., 2014, Система соціального захисту населення як соціальний, економічний та політичний стабілізатор розвитку суспільства, Наукові записки Національного університету «Острозька академія», Серія: Економіка, 27, 108-113.

Уряд вирішує проблеми забезпечення доступним житлом учасників АТО і ВПО, 2017, [in:] Державна служба України у справах ветеранів війни та учасників антитерористичної операції, http://dsvv.gov.ua/aktualnipytannya/uryad-vyrishuje-problemy-zabezpechennyadostupnym-zhytlom-uchasnykiv-ato-i-vpo.html [28.10.2017].

Уряд затвердив Порядок організачії сочіальної та професійної адаптації учасників АТO, 2017, [in:] Державна служба України у справах ветеранів війни та учасників антитерористичної операції, http://dsvv. gov.ua/aktualni-pytannya/uryad-zatverdyv-poryadokorhanizatsiji-sotsialnoji-ta-profesijnoji-adaptatsijiuchasnykiv-ato.html [08.09.2017].

Уряд схвалив питання оновлення системи профорієнтації та адаптації військовослужбовців, 2017, [in:] Державна служба України у справах ветеранів війни та учасників антитерористичної операції, http://dsvv. gov.ua/aktualni-pytannya/uryad-shvalyv-pytannyaonovlennya-systemy-proforijentatsiji-ta-adaptatsijivijskovosluzhbovtsiv.html [08.09.2017].

Чижов Д., 2016, Нормативно-правове забезпечення права на соціальний захист учасників АТО та членів їх сімей, Вісник Начіонального університету «Львівська політехніка», Юридичні науки, 845, 173-182.

Щодо надання послуг державної служби зайнятості безробітним з числа військовослужбовців, які брали участь в АТО. Аналітична записка, 2017, [in:] Державна служба зайнятості http://www.dcz.gov.ua/statdatacatalog/ document?id=393494 [29.10.2017].

Як допомогти учаснику АТО прачевлаштуватися, 2017, [in:] Державна служба України у справах ветеранів війни та учасників антитерористичної операції, http://dsvv.gov.ua/aktualni-pytannya/yak-dopomohtyuchasnyku-ato-pratsevlashtuvatysya.html [29.10.2017]. 